NOTE

\title{
Perkinsus marinus in Crassostrea gigas in the Gulf of California
}

\author{
T. L. Enríquez-Espinoza, J. M. Grijalva-Chon*, R. Castro-Longoria, \\ J. Ramos-Paredes \\ Departamento de Investigaciones Científicas y Tecnológicas, Universidad de Sonora, \\ Colosio entre Reforma y Sahuaripa s/n, Hermosillo, Sonora, Mexico
}

\begin{abstract}
To determine the agent responsible for the massive mortalities of the Pacific oyster Crassostrea gigas in northwest Mexico, 30 oysters were sampled after a severe mortality event in 2006 along the Sonoran coast. Histological analyses revealed the presence of a protozoan and Ray's fluid thioglycollate medium (RFTM) assays showed the presence of Perkinsus sp., identified as P. marinus from the DNA sequence of the internal transcribed spacer (ITS) of the ribosomal RNA (rRNA) gene complex. PCR analyses for Marteilia refringens, M. sydneyi, and Haplosporidium costale were negative. P. marinus presence in the Pacific oyster may be responsible for massive mortalities of the oyster, along with other environmental factors in the Gulf of California.
\end{abstract}

KEY WORDS: Perkinsus marinus - Pacific oyster · Crassostrea gigas · Aquaculture · Gulf of California $\cdot$ Ray's fluid thioglycollate medium $\cdot$ Ribosomal DNA

\section{INTRODUCTION}

The Pacific oyster Crassostrea gigas is a species widely cultured around the world, but sometimes mass mortalities jeopardize the farming activity; there are several pathogen species that threaten the organisms' health and that may be partially responsible for summer mortalities, together with environmental and reproductive factors (Samain et al. 2007).

In Mexico the culturing of Crassostrea gigas using several culture methods began in the 1970s along the Baja California Peninsula coast, with further success along the Mexican Pacific coast, including the Gulf of California (Gallo-García et al. 2001, Vásquez-Yeomans et al. 2004). The cultures were successful for $>10 \mathrm{yr}$, but by the end of the 1990s the cultures started to decline because of severe mortality episodes affecting all size-classes, with Sonora and Baja California Sur being the more affected states (Cáceres-Martínez \&
Vásquez-Yeomans 2003). At present oyster culture activity has stagnated due to poor investment, lack of incentives, and unknown causes of mortality. To explain the mortalities, multiple hypotheses have been expressed by farmers: El Niño, contamination, red tides, fluctuations in food abundance, poor genetic variability, and unknown pathogens.

In 2006 multidisciplinary research began to investigate the mortality in Crassostrea gigas cultures along the Sonoran coast in the Gulf of California. A pathological research approach was used to explore the possible presence of protozoan parasites because several species have been associated with massive mortalities in mollusc cultures around the world (Berthe et al. 2004, Burreson \& Ford 2004, Villalba et al. 2004, Audemard et al. 2008). The present study confirms the presence of Perkinsus marinus in C. gigas as a probable contributor to the massive mortalities in the farmed oysters of the Gulf of California. 


\section{MATERIALS AND METHODS}

From July to August 2006 severe mortality devastated the oyster cultures along the Sonoran coast. In September 2006, 30 live oysters were taken from 3 culture sites (10 oysters each) along the Sonoran coast at Estero Santa Barbara, Estero La Cruz, and Estero Morua with shell lengths between 7 and $10 \mathrm{~cm}$ (Table 1). The oysters were transported to our laboratory for histopathological analyses using standard hematoxilin-eosin staining to look for lesions in the intestine, gonad, gills, and mantle according to OIE (2009), Bondad-Reantaso et al. (2001), and Bower et al. (1994). At the same time, Ray's fluid thioglycollate medium (RFTM) assay (OIE 2009) was done on all oysters using small tissue sections of the abductor muscle, intestine, and digestive gland, which were stained with Lugol's iodine on a glass slide and observed microscopically. This test is considered presumptive for Perkinsus spp., although some dinoflagellate species and a Perkinsus spp.-like organism can give positive results with RFTM (Novoa et al. 2002). Remaining tissues were frozen at $-70^{\circ} \mathrm{C}$.

DNA extraction was done of all the RFTM cultures and all frozen tissue using the QIAamp DNA Mini Kit according to the manufacturer's instructions (QIAGEN). PCR was done using the Perkinsus spp.-specific internal transcribed spacer (ITS) region primers PerkITS-85 (5'-CCG CTT TGT TTG GAT CCC-3') and PerkITS-750 (5'-ACA TCA GGC CTT CTA ATG ATG3') (Casas et al. 2002, Audemard et al. 2004). These primers amplify DNA for all Perkinsus spp. with the exception of $P$. qugwadi. PCR reactions were done with Ready-to-Go PCR beads (GE Healthcare) with $30 \mathrm{ng}$ DNA and $0.01 \mu \mathrm{g}$ of each primer in a total volume of $25 \mu \mathrm{l}$. Because PCR conditions recommended by Casas et al. (2002) and Audemard et al. (2004) generated weak and inconsistent DNA bands, PCR assays were done by looking for the best PCR conditions, which were an initial denaturalization at $94^{\circ} \mathrm{C}$ for 5 min, 35 cycles of $94^{\circ} \mathrm{C}$ for $30 \mathrm{~s}, 60^{\circ} \mathrm{C}$ for $30 \mathrm{~s}, 72^{\circ} \mathrm{C}$ for 1 min, and a final step of $72^{\circ} \mathrm{C}$ for $7 \mathrm{~min}$. Consistency was checked with 5 replicates of the PCR analysis.

PCR products of the PerkITS-85 and PerkITS-750 primers were visualized on $2 \%$ agarose gels stained

Table 1. Crassostrea gigas. Sampling locations, number, and size (mean \pm SD of C. gigas analyzed for the presence of Perkinsus marinus

\begin{tabular}{lccc|}
\hline Sampling location & Geographical coordinates & $\begin{array}{c}\text { No. of } \\
\text { oysters }\end{array}$ & $\begin{array}{c}\text { Shell length } \\
(\mathrm{cm})\end{array}$ \\
\hline Estero Santa Barbara & $26^{\circ} 41^{\prime} 39^{\prime \prime} \mathrm{N}, 109^{\circ} 39^{\prime} 80^{\prime \prime} \mathrm{W}$ & 10 & $9.25 \pm 0.92$ \\
Estero La Cruz & $28^{\circ} 47^{\prime} 34^{\prime \prime} \mathrm{N}, 111^{\circ} 53^{\prime} 27^{\prime \prime} \mathrm{W}$ & 10 & $7.55 \pm 0.86$ \\
Estero Morua & $31^{\circ} 17^{\prime} 19^{\prime \prime} \mathrm{N}, 113^{\circ} 26^{\prime} 64^{\prime \prime} \mathrm{W}$ & 10 & $8.35 \pm 0.58$ \\
\hline
\end{tabular}

with ethidium bromide. The DNA bands were purified using the Rapid Gel-Extraction System (Marligen Bioscience). To corroborate the species identity, the primer PmarITS-600R (5'-CGA GTT TGC GAG TAC CTC KAG AG-3') (Audemard et al. 2004), specific to Perkinsus marinus, was used with primer PerkITS-85 in PCR reactions with $60 \mathrm{ng}$ of purified amplicon generated by the primers PerkITS-85 and PerkITS-750. For this PCR reaction, Ready-to-Go PCR beads were used with the same PCR conditions detailed in the previous paragraph. All reactions included a negative control without DNA. PCR products from RFTM cultures were sequenced by Macrogen.

The sequences obtained were analyzed using the basic local alignment search tool (BLAST) of the National Center for Biotechnology Information (NCBI), USA. A multiple sequence alignment was also done using ClustalX (Thompson et al. 1997) with some Perkinsus spp. sequences reported in GenBank.

Additionally, nested PCR reactions were done using frozen tissue to look for Marteilia refringens using primers MT-1 (5'-GCC AAA GAC ACG CCT CTA C$3^{\prime}$ ) and MT-2 (5'-AGC CTT GAT CAC ACG CTT T-3') for a first reaction, and MT-1B (5'-CGC CAC TAC GAC CGT AGC CT-3') and MT-2B (5'-CGA TCG AGT AAG TGC ATG CA-3') for the nested reaction, according to procedures described in López-Flores et al. (2004). M. sydneyi was screened with primers PRO2 (5'-TCA AGG GAC ATC CAA CGG TC-3') and LEG1 (5'-CGA TCT GTG TAG TCG GAT TCC GA-3') according to Kleeman \& Adlard (2000). For Haplosporidium costale, the primers SSO-A (5'-CAC GAC TTT GGC AGT TAG TTT TG-3') and SSO-B (5'-CGA ACA AGC GCT AGC AGT ACA T-3') were used according to OIE (2003). All PCR products were visualized on $2 \%$ agarose gels.

\section{RESULTS}

The observation of histological sections showed alterations in the tissue structure in various organs, such as the intestinal epithelium, gills, digestive gland, and connective tissue. In the intestinal epithelia, the arrangement of the columnar cells showed severe changes, accompanied by an eosinophilic reaction, presumably indicating the presence of parasites in the tissue. Also, gill lesions showed severe vacuolization, necrosis, and the invasive presence of unidentified rosettelike parasites. In the digestive gland, tubules were also seen with the same types of parasites with alteration of the epithelium, probably as a result of this 

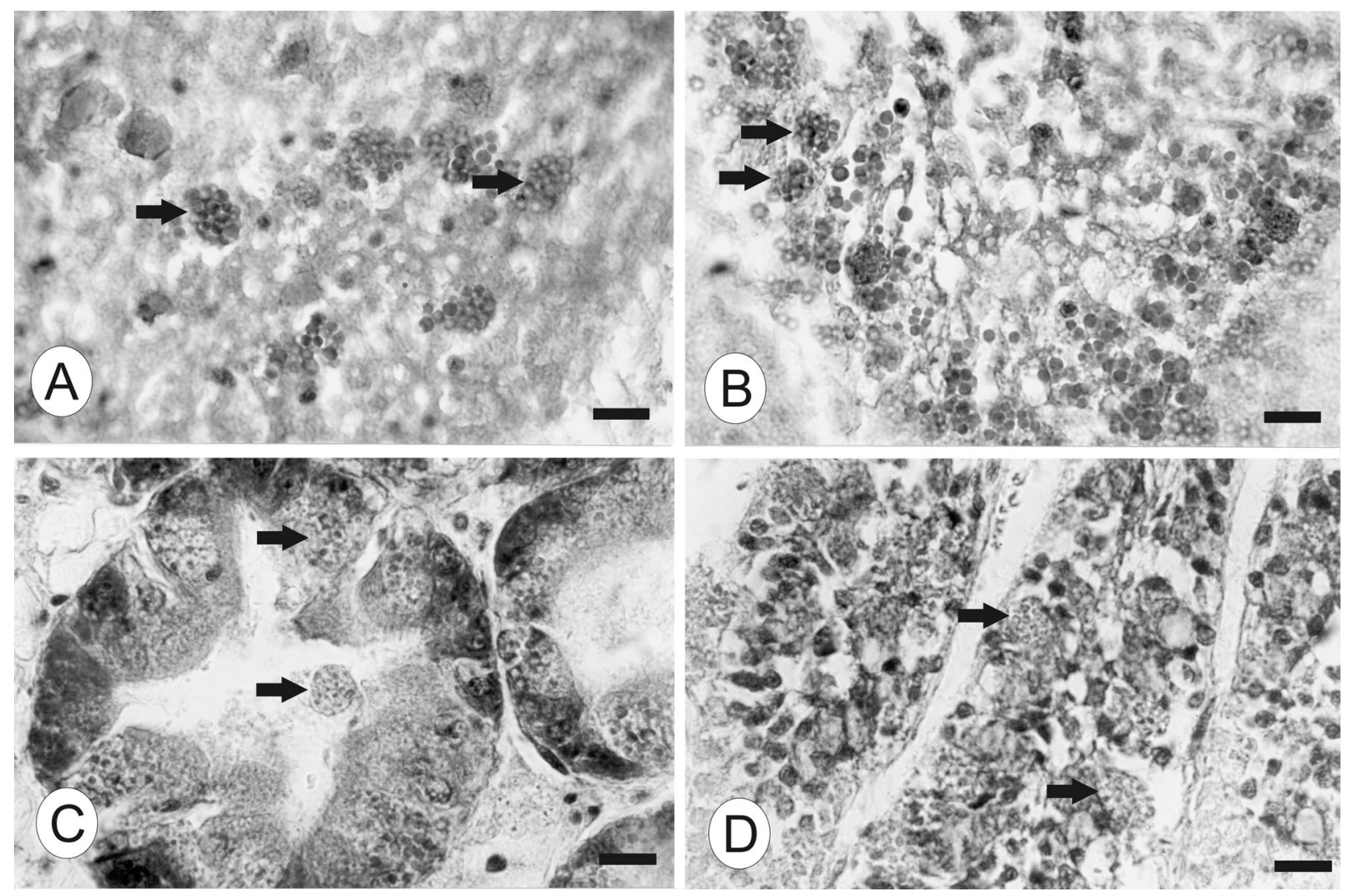

Fig. 1. Crassostrea gigas. Histological tissue sections depicting severe damage caused by the invasive presence of schizonts (black arrows) in the $(\mathrm{A}, \mathrm{B})$ gut, $(\mathrm{C})$ digestive gland, and $(\mathrm{D})$ gills. Scale bar $=15 \mu \mathrm{m}$

invasion (Fig. 1). These histological lesions coincided with the ones reported for Perkinsus marinus infection of Crassostrea virginica (Burreson et al. 1994), where rosettes were seen in the digestive epithelia, similar to those found in C. gigas of Sonora. The tissues analyzed by the RFTM assay showed dark blue spherical bodies, which were hypnospores characteristic for Perkinsus spp. (Fig. 2). There was $100 \%$ prevalence of infection for samples from the 3 locations, with infection intensities ranging from $3558 \pm 3197$ to $165112 \pm 155404$ hypnospores $\mathrm{g}^{-1}$ tissue (Table 2).

PCR analyses for Marteilia refringens, M. sydneyi, and Haplosporidium costale were negative. Only the samples from Estero La Cruz were positive with both combinations of PerkITS-85 plus PerkITS-750 and PerkITS-85 plus PmarITS600R primers, which consistently amplified bands of 666 and 475 bp (Fig. 3) from RFTM tissue cultures. By the time we had determined what the best PCR conditions were, the fresh frozen tissue samples were lost and no PCR analyses were possible. Two sequences were obtained; the one obtained with primers PerkITS-85 and PmarITS-600R confirmed the Perkinsus marinus identity and matched the sequence obtained with primers PerkITS-85 and PerkITS-750 (GenBank accession no. GQ861511). The entire sequence of $666 \mathrm{bp}$ that included the primer recognition sequences was analyzed by BLAST in GenBank and showed 98 to $100 \%$ identity with the ITS region of $58 P$. marinus entries, having $100 \%$ identity with 2 of them (GenBank accession nos. AY295199 and AY295198), 93 to $94 \%$ identity with 23 P. olseni entries,

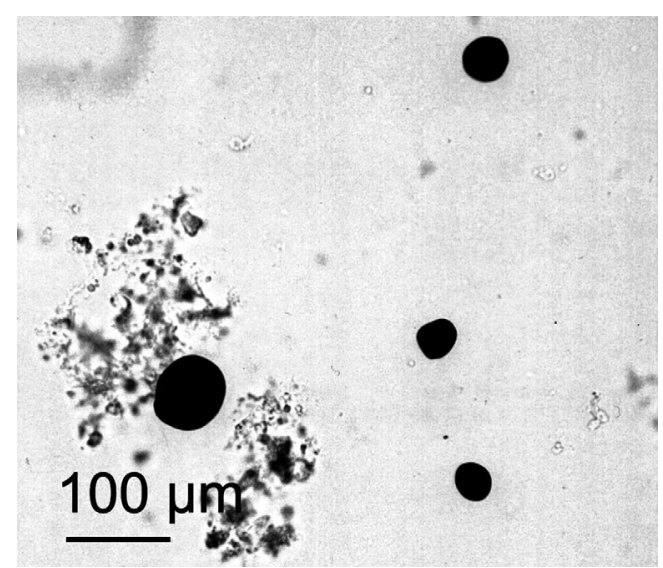

Fig. 2. Perkinsus marinus from Crassostrea gigas. P. marinus hypnospores from Ray's fluid thioglycollate medium culture and stained with Lugol's iodine, obtained from the gut of C. gigas 
Table 2. Perkinsus marinus in Crassostrea gigas. Prevalence of infection, quantification, and PCR analysis. RFTM: Ray's fluid thioglycollate medium

\begin{tabular}{|lcccc|}
\hline $\begin{array}{l}\text { Sampling } \\
\text { location }\end{array}$ & $\begin{array}{c}\text { Histology prevalence } \\
(\%)\end{array}$ & $\begin{array}{c}\text { RFTM prevalence } \\
(\%)\end{array}$ & $\begin{array}{c}\text { Hypnospores g } \\
\text { tissue (mean } \pm \text { SD) }\end{array}$ & PCR from RFTM tissue \\
\hline $\begin{array}{l}\text { Estero Santa Barbara } \\
\text { Estero La Cruz }\end{array}$ & 100 & 100 & $3558 \pm 3197$ & Negative \\
Estero Morua & 100 & 100 & $165112 \pm 155404$ & Positive \\
& 100 & 100 & $6220 \pm 4609$ & Negative \\
\hline
\end{tabular}

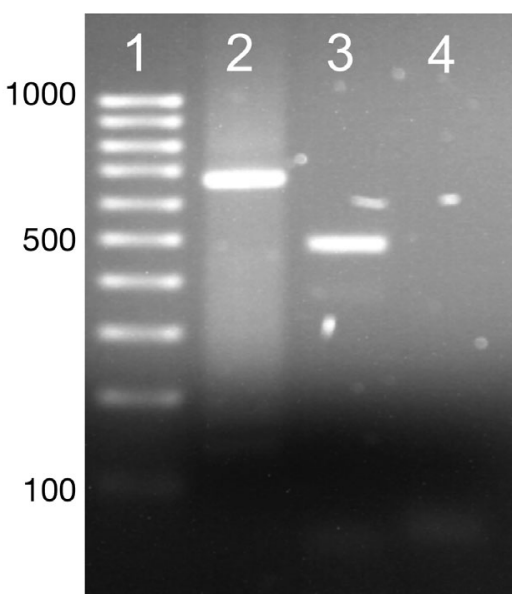

Fig. 3. Agarose gel of PCR amplicons obtained from Ray's fluid thioglycollate medium cultures. Lane 1: $100 \mathrm{bp}$ molecular standard. Lane 2: amplicon with primers PerkITS-85 and PerkITS-750. Lane 3: amplicon with primers PerkITS-85 and PmarITS-600R. Lane 4: negative control

$94 \%$ identity with $13 P$. atlanticus entries, 92 to $93 \%$ identity with $3 P$. honshuensis entries, and had coverage of 93 to $100 \%$ overall.

\section{DISCUSSION}

The massive mortality in Crassostrea gigas cultures along the Pacific coast of Mexico, mostly from October to November and March to May, has severely threatened the existence of $>30$ oyster farms. In our search for a pathogen involved in those mortalities, our histological analyses suggested the presence of a protozoan of an unknown species. The RFTM analysis, a routine and standard method to detect the presence of Perkinsus spp. in mollusc species (Burreson 2000, Coss et al. 2001, Reece \& Dungan 2005), was positive in our samples. The discrepancy between positive RFTM assay and negative PCR results has been explained thus: it can occur because of low infection levels, with $<1$ parasite $20 \mathrm{mg}^{-1}$ tissue, and because of the patchy distribution of parasites in host tissues (Renault 2008). Our observed discrepancies in RFTM and PCR results at Estero Santa Barbara and Estero Morua can be explained by the infection level: at Estero La Cruz the infection level was 44 -fold and 25-fold greater than that at Estero Santa Barbara and Estero Morua, respectively.

The true Perkinsus species identity was confirmed with the DNA sequence of the ITS of the ribosomal RNA (rRNA) gene complex. ITS sequences are preferred over non-transcribed spacer (NTS) sequences because of their ability to detect more species (Renault 2008, OIE 2009). The distribution of $P$. marinus comprises the East and Gulf coasts of the USA (Villalba et al. 2004); however, its presence along the Pacific coast of Mexico was recently reported in the pleasure oyster Crassostrea corteziensis in Nayarit by CáceresMartínez et al. (2008). The origin of this parasite on the Mexican Pacific coast is unknown but the movement of oysters in and out of the Gulf of California and acquisition of infected spat from abroad may contribute to the spread of the infection. The presence of $P$. marinus in C. gigas in the Gulf of California implies that the wild mollusc species in the area could also be infected. If this is true, the eradication of $P$. marinus in $C$. gigas cultures is an impossible task and oyster farmers only have the option to follow good culture practices to minimize the impact of the illness.

Mollusc species have different responses to a pathogenic protozoan infection, and environmental factors such as temperature and salinity are involved in the infective process (Burreson et al. 1994, Chu 1996, La Peyre et al. 2006). Perkinsosis is an illness associated with warm waters (La Peyre et al. 2006), which is a characteristic of the Gulf of California, where surface water temperatures on oyster farms reaches 30 to $32^{\circ} \mathrm{C}$ in summer. However, because of the wide range of salinities and temperatures that can be found along the $>1000 \mathrm{~km}$ long Gulf of California, it is necessary to determine which areas have a greater risk for Perkinsus marinus infections.

The massive mortality events in the Gulf of California could be generated by a complex environmenthost-parasite interaction, so that the contribution of Perkinsus marinus in those events should be reviewed in the light of the possible presence of other parasitic species and the wide environmental scenarios along the Gulf of California associated with its geographic 
characteristics and seasonal variability. Continuous monitoring of cultured oyster and wild clam species is necessary to determine the prevalence of the pathogen and the infection level following OIE (2009) recommendations.

Acknowledgements. Thanks to Secretaría de Agricultura, Ganadería, Desarrollo Rural, Pesca y Alimentación (SAGARPA) for financial support. The Instituto de Acuacultura del Estado de Sonora and Comité de Sanidad Acuícola del Estado de Sonora gave logistical support. The oyster farmers provided organisms for analyses. Thanks to S. D. MorenoVelásquez, M. Lastra-Encinas, M. R. Acedo-Valdez, and A. Martínez-Durazo for technical support. We acknowledge a grant to T.L.E.-E. from Consejo Nacional de Ciencia y Tecnología. Thanks to Dr. Ellis Glazier for editing the Englishlanguage text.

\section{LITERATURE CITED}

Audemard C, Reece KS, Burreson EM (2004) Real-time PCR for detection and quantification of the protistan parasite Perkinsus marinus in environmental waters. Appl Environ Microbiol 70:6611-6618

Audemard C, Carnegie RB, Burreson EM (2008) Shellfish tissues evaluated for Perkinsus spp. using the Ray's fluid thioglycollate medium culture assay can be used for downstream molecular assays. Dis Aquat Org 80:235-239

Berthe FCJ, Le Roux F, Adlard RD, Figueras A (2004) Marteiliosis in molluscs: a review. Aquat Living Resour 17:433-448

Bondad-Reantaso MG, McGladdery SE, East I, Subasinghe RP (eds) (2001) Asia diagnostic guide to aquatic animal diseases. FAO Fish Tech Pap 402(Suppl 2), FAO, Rome

Bower SM, McGladdery SE, Price IM (1994) Synopsis of infectious disease and parasites of commercially exploited shellfish. Annu Rev Fish Dis 4:1-199

Burreson EM (2000) Molecular diagnostics for the oyster pathogens Haplosporidium nelsoni (MSX disease) and Perkinsus marinus (Dermo disease) in Chesapeake Bay, Virginia, USA. In: Walker P, Subasinghe R (eds) DNAbased molecular diagnostic techniques: research needs for standardization and validation of the detection of aquatic animal pathogens and diseases. Report and Proceedings of the Joint FAO/NACA/CSIRO/ACIAR/DFID Expert Workshop. Bangkok, 7-9 Feb 1999. FAO Fish Tech Pap 395. FAO, Rome, p 71-77

Burreson EM, Ford SE (2004) A review of recent information on the Haplosporidia, with special reference to Haplosporidium nelson (MSX disease). Aquat Living Resour 17:499-517

Burreson E, Álvarez R, Martínez V, Macedo L (1994) Perkinsus marinus (Apicomplexa) as a potential source of oyster Crassostrea virginica mortality in coastal lagoons of Tabasco, Mexico. Dis Aquat Org 20:77-82

Cáceres-Martínez J, Vásquez-Yeomans R (2003) Virus asociado a erosión branquial en el ostión japonés Crassostrea gigas y su relación con episodios de mortalidad masiva en el NW de México. Bol Programa Nacional de Sanidad Acuícola Red Diagnóstico, Año 6, 1(21):15-18

Cáceres-Martínez J, Vásquez-Yeomans R, Padilla-Lardizábal G, Portilla MR (2008) Perkinsus marinus in pleasure oyster

Editorial responsibility: Mike Hine,

Fouras, France
Crassostrea corteziensis from Nayarit, Pacific coast of Mexico. J Invertebr Pathol 99:66-73

Casas SM, La Peyre JF, Reece KS, Azevedo C, Villalba A (2002) Continuous in vitro culture of the carpet shell clam Tapes decussatus protozoan parasite Perkinsus atlanticus. Dis Aquat Org 52:217-231

Chu FLE (1996) Laboratory investigations of suceptibility, infectivity, and transmission of Perkinsus marinus in oysters. J Shellfish Res 15:57-66

Coss CA, Robledo JAF, Vasta GR (2001) Fine structure of clonally propagated in vitro life stages of a Perkinsus sp. isolated from the Baltic clam Macoma balthica. J Eukaryot Microbiol 48:38-51

Gallo-García MC, García-Ulloa M, Godínez-Siordia D, Rivera-Gómez K (2001) Estudio preliminar sobre el crecimiento y sobrevivencia del ostión del Pacífico Crassostrea gigas (Thunberg, 1873) en Barra de Navidad, Jalisco, México. Universidad Ciencia 17:83-91

> Kleeman SN, Adlard RD (2000) Molecular detection of Marteilia sydneyi, pathogen of Sydney rock oysters. Dis Aquat Org 40:137-146

> La Peyre M, Casas S, La Peyre J (2006) Salinity effects on viability, metabolic activity and proliferation of three Perkinsus species. Dis Aquat Org 71:59-74

> López-Flores I, De la Herran R, Garrido-Ramos MA, Navas JI, Ruíz-Rejón C, Ruíz-Rejón YM (2004) The molecular diagnosis of Marteilia refringens and differentiation between Marteilia strains infecting oysters and mussels based on the rDNA IGS sequence. Parasitology 129: 411-419

Novoa B, Ordáz MC, Figueras A (2002) Hypnospores detected by RFTM in clam (Ruditapes decussatus) tissues belong to two different protozoan organisms, Perkinsus atlanticus and a Perkinsus-like organism. Aquaculture 209:11-18

OIE (2003) Manual of diagnostic tests for aquatic animals. World Organization for Animal Health, Paris

OIE (2009) Manual of diagnostic tests for aquatic animals. World Organization for Animal Health, Paris

Reece K, Dungan C (2005) Perkinsus sp. infections of marine molluscs. In: AFS-FHS (American Fisheries Society-Fish Health Section). FHS blue book: Suggested procedures for the detection and identification of certain finfish and shellfish pathogens, 2005 edn. AFS/FHS, Bethesda, MD, Ch. 5.2, p 1-17

Renault TC (2008) Genomics and mollusc pathogens: trends and perspective. J Vet Clin Sci 1:36-46

Samain JF, Dégremont L, Sotetchnik P, Haure J and others (2007) Genetically based resistance to summer mortality in the Pacific oyster (Crassostrea gigas) and relationship with physiological, immunological characteristics and infection processes. Aquaculture 268:227-243

Thompson JD, Gibson TJ, Plewniak F, Jeanmougin F, Higgins DG (1997) The ClustalX windows interface: flexible strategies for multiple sequence alignment aided by quality analysis tools. Nucleic Acids Res 25:4876-4882

Vásquez-Yeomans R, Cáceres-Martínez J, García-Ortega AM (2004) Bacterias aisladas de las branquias del ostión japonés Crassostrea gigas cultivado en Bahía Falsa, Baja California, México. An Inst Biol Univ Nac Auton Mex Zool 75:237-243

> Villalba A, Reece KS, Ordás MC, Casas SM, Figueras A (2004) Perkinsosis in molluscs: a review. Aquat Living Resour 17: 411-432

Submitted: October 26, 2009; Accepted: January 11, 2010

Proofs received from author(s): March 19, 2010 